\title{
Associations between XRCC3 Thr241Met polymorphisms and breast cancer risk: systematic-review and meta-analysis of 55 case-control studies
}

\author{
Sepideh Dashti ${ }^{1 \dagger}$, Zahra Taherian-Esfahani ${ }^{1 \dagger}$, Abbasali Keshtkar ${ }^{2}$ and Soudeh Ghafouri-Fard ${ }^{1 *}$ (D)
}

\begin{abstract}
Background: The X-ray repair cross-complementing group 3 (XRCC3) is an efficient component of homologous recombination and is required for the preservation of chromosomal integrity in mammalian cells. The association between Thr241Met single-nucleotide polymorphism (SNP) in this gene and susceptibility to breast cancer has been assessed in several studies. Yet, reports are controversial. The present meta-analysis has been designed to identify whether this SNP is associated with susceptibility to breast cancer.

Methods: We performed a systematic review and meta-analysis for retrieving the case-control studies on the associations between T241 M SNP and the risk of breast cancer. Crude odds ratios (ORs) and 95\% confidence intervals ( $\mathrm{Cls}$ ) were calculated to verify the association in dominant, recessive, and homozygote inheritance models.

Results: We included 55 studies containing 30,966 sporadic breast cancer cases, 1174 familial breast cancer cases and 32,890 controls in the meta-analysis. In crude analyses, no association was detected between the mentioned SNP and breast cancer risk in recessive, homozygote or dominant models. However, ethnic based analysis showed that in sporadic breast cancer, the SNP was associated with breast cancer risk in Arab populations in homozygous (OR $(95 \% \mathrm{Cl})=3.649(2.029-6.563), p=0.0001)$ and recessive models $(\mathrm{OR}(95 \% \mathrm{Cl})=4.092(1.806-9.271), p=0.001)$. The association was significant in Asian population in dominant model $(\mathrm{OR}(95 \% \mathrm{Cl})=1.296, p=0.029)$. However, the associations was significant in familial breast cancer in mixed ethnic-based subgroup in homozygote and recessive models (OR (95\% Cl) $=0.451 \quad(0.309-0.659), p=0.0001, \quad O R \quad(95 \% \quad C l)=0.462 \quad(0.298-0.716), p=0.001$ respectively).

Conclusions: Taken together, our results in a large sample of both sporadic and familial cases of breast cancer showed insignificant role of Thr241Met in the pathogenesis of this type of malignancy. Such results were more conclusive in sporadic cases. In familial cases, future studies are needed to verify our results.
\end{abstract}

Keywords: Genes, Neoplasm, Single nucleotide polymorphism, Breast Cancer

\footnotetext{
* Correspondence: s.ghafourifard@sbmu.ac.ir

†Sepideh Dashti and Zahra Taherian-Esfahani contributed equally to this work.

'Department of Medical Genetics, Shahid Beheshti University of Medical

Sciences, Tehran, Iran

Full list of author information is available at the end of the article
}

(c) The Author(s). 2019 Open Access This article is distributed under the terms of the Creative Commons Attribution 4.0 International License (http://creativecommons.org/licenses/by/4.0/), which permits unrestricted use, distribution, and reproduction in any medium, provided you give appropriate credit to the original author(s) and the source, provide a link to the Creative Commons license, and indicate if changes were made. The Creative Commons Public Domain Dedication waiver (http://creativecommons.org/publicdomain/zero/1.0/) applies to the data made available in this article, unless otherwise stated. 


\section{Background}

Breast cancer ranks first among all women's cancers regarding its incidence and rank second among them regarding its cancer-related mortality rate [1]. Several genetic and environmental factors have been associated with breast cancer risk. Among the most relevant factors is the ability to repair DNA double strand break (DSB). The homologous recombination (HR) and the non-homologous end-joining (NHEJ) pathways have been developed in eukaryotic cells for repair of such defects [2]. Numerous single nucleotide polymorphisms (SNPs) within genes coding the NHEJ pathway have been associated with breast cancer risk [3]. More importantly, the mostly recognized breast cancer susceptibility genes $B R C A 1$ and BRCA2 participate in the process of $H R$. Deficiencies in HR have been detected both in $B R C A 1 / 2$ germline mutation-associated and remarkable fraction BRCA1/2 wild-type breast cancer patients [4]. The $X$-ray repair cross-complementing group 3 (XRCC 3 ) is an efficient component of $\mathrm{HR}$ and is required for the preservation of chromosomal integrity in mammalian cells [5]. Consequently, it has been regarded as a supposed candidate gene for breast cancer susceptibility. However, the data regarding its participation in breast cancer risk are inconsistent. Hang et al. conducted a meta-analysis of 48 case-control studies (including 14 studies in breast cancer) and reported that XRCC3 Thr241Met significantly increased risk of breast cancer. However, they suggested that a single larger study should be performed to assess tissue-specific cancer risk in different ethnicities [6]. Garci'a-Closas et al. meta-analyzed the studies in Caucasian populations (10,979 cases and 10,423 controls) and reported a weak association between homozygous variants for XRCC3 Thr241Met and risk of breast cancer. They concluded that this variant is implausible to have a considerable role in breast cancer risk. However, they suggested studies with larger sample sizes to assess probable underlying gene-gene interactions or associations in ethnic-based subgroups [7]. Lee et al. in their meta-analysis of 12 studies demonstrated that Thr/Met and Met/Met weakly elevated the risk of breast cancer compared to Thr/Thr genotype [8]. Economopoulos et al. conducted a meta-analysis on 20 case-control studies in non-Chinese individuals and three case-control studies on Chinese individuals and reported association between $\mathrm{T}$ allele of this polymorphism (corresponding to Met) and breast cancer risk in recessive model. However, the association was only detected in non-Chinese population [9]. He et al. reported the mentioned association in recessive and additive models, but suggested conduction of a study with the larger sample size to assess gene-environment interaction [10]. In another study, $\mathrm{He}$ et al. have conducted a meta-analysis of 157 case-control studies including 34 studies in breast cancer $(22,917$ cases and 24,313 controls) and suggested the XRCC3 Thr241Met as a susceptibility locus for breast cancer, especially in Caucasians [11]. Mao et al. demonstrated a significantly higher risk of breast cancer in heterozygote model but not in other models. Such association was significant in Asians. Based on the reported weak association, they suggested conduction of a study with larger sample size [12]. Finally, using 23 case-control studies, Chai et al. reported association between the mentioned polymorphism and breast cancer risk, especially in Asian populations and in patients without family history of breast cancer [13].

Therefore, according to inconclusive results of the previous meta-analyses and lack of systematic review in this regard, we conducted a systematic review and meta-analysis to assess the association between the Thr241Met SNP (rs861539) within XRCC3 and breast cancer risk in diverse inheritance models.

\section{Methods \\ Registration}

We conducted the present systematic review protocol according to the preferred reporting items for systematic review and meta-analysis protocols (PRISMA-P) [14]. We also registered the study protocol on the international prospective register of systematic review (PROSPERO) network. The registration number was CRD42018104217.

\section{Information source and searching strategy}

We searched PubMed, Scopus, EMBASE, Web of Science and ProQuest databases, the key journals (Breast Cancer Research and Treatment, Cancer Research), conferences/ congress research papers (as Grey literature) and the reference list of the included primary studies until March $2018 \mathrm{~T}(1990 / 01 / 01: 2018 / 03 / 31)$ using the following syntaxes: "x-ray repair cross-complementing group 3" or "XRCC3"and"polymorphisms" or "single nucleotide polymorphism" and "breast tumor" or "breast cancer" and "rs861539" or "c.722C > T" or "p.Thr241Met" or "T241 M" (see Additional file 1). The complete search syntaxes were developed based on $\mathrm{MeSH}$ database and Emtree. The syntaxes for each database are shown in supplementary file. We did not implement any language restriction.

\section{Eligibility criteria and selection process}

We included: i) all observational studies such as crosssectional, case-control and cohort studies ii) studies that assessed associations between Thr241Met within XRCC3 and breast cancer risk. iii) Studies with available genotype frequencies in both case and control groups. We excluded books, reviews, editorial, letters and articles 


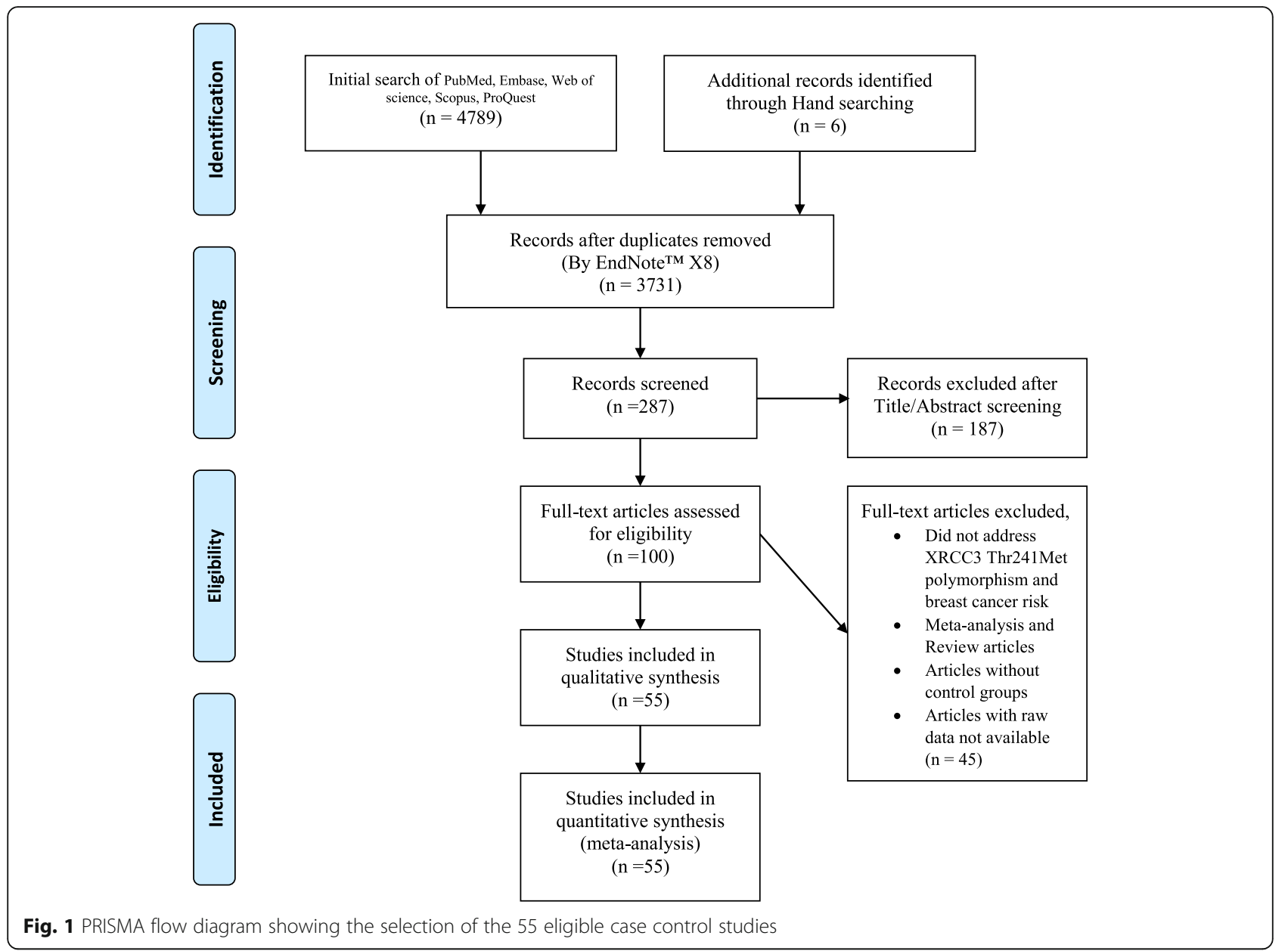

Table 1 General characteristics of studies reporting associations in familial breast cancer (HB: hospital based, PB: population based, N/M: Not mentioned, HWE: Hardy-Weinberg Equilibrium, NOS: The Newcastle-Ottawa Scale, Quality of studies based on NOS star scoring system: 1-2 stars: poor, 3-5 stars: fair and 6-10 stars: good)

\begin{tabular}{|c|c|c|c|c|c|c|c|c|c|c|c|c|c|c|c|c|}
\hline \multirow[t]{2}{*}{ First Author } & \multirow[t]{2}{*}{ Year } & \multirow[t]{2}{*}{ Society } & \multirow[t]{2}{*}{ Country } & \multirow[t]{2}{*}{ Ethnicity } & \multirow{2}{*}{$\begin{array}{l}\text { Genotyping } \\
\text { Method }\end{array}$} & \multirow{2}{*}{$\begin{array}{l}\text { Case- } \\
\text { enrollment } \\
\text { strategy }\end{array}$} & \multicolumn{4}{|c|}{ Frequency in Cases } & \multicolumn{4}{|c|}{ Frequency in Controls } & \multirow[t]{2}{*}{ HWE } & \multirow{2}{*}{$\begin{array}{l}\text { NOS } \\
\text { score }\end{array}$} \\
\hline & & & & & & & $\pi$ & $\mathrm{TM}$ & MM & Total & $\pi$ & $\mathrm{TM}$ & MM & Total & & \\
\hline Costa & 2007 & $\mathrm{HB}$ & Portugal & Caucasian & PCR-RFLP & Prevalent & 40 & 29 & 12 & 81 & 225 & 140 & 66 & 431 & 0 & 5 \\
\hline Dufloth & 2005 & $H B$ & Brazil & Mixed & PCR-RFLP & Prevalent & 27 & 18 & 7 & 52 & 68 & 35 & 15 & 118 & 0.005 & 3 \\
\hline Figueiredo & 2004 & PB & Canada & Caucasian & MALDI-TOF MS & Incident & 29 & 38 & 16 & 83 & 13 & 20 & 4 & 37 & 0.341 & 9 \\
\hline Forsti & 2004 & $\mathrm{~PB}$ & Finland & Caucasian & PCR-RFLP & Prevalent & 72 & 85 & 15 & 172 & 89 & 88 & 25 & 202 & 0.654 & 4 \\
\hline Smith b & 2003 & $\mathrm{HB}$ & USA & Caucasian & PCR-RFLP & Incident & 10 & 14 & 3 & 27 & 42 & 55 & 24 & 121 & $>0.05$ & 7 \\
\hline Vral & 2011 & $H B$ & Italy & Caucasian & $\begin{array}{l}\text { PCR-RFLP or } \\
\text { SnapShot } \\
\text { technique }\end{array}$ & $\mathrm{N} / \mathrm{M}$ & 60 & 87 & 23 & 170 & 54 & 84 & 30 & 168 & 0.964 & 2 \\
\hline $\begin{array}{l}\text { Gonzalez- } \\
\text { Hormazabal }\end{array}$ & 2012 & $\mathrm{~PB}$ & Chile & Mixed & Taq-Man & Prevalent & 187 & 103 & 32 & 322 & 335 & 209 & 23 & 567 & 0.177 & 7 \\
\hline Jara & 2010 & PB & Chile & Mixed & $\begin{array}{l}\text { Conformation- } \\
\text { sensitive gel } \\
\text { electrophoresis } \\
\text { (CSGE) }\end{array}$ & Prevalent & 149 & 91 & 27 & 267 & 296 & 182 & 22 & 500 & 0.52 & 8 \\
\hline
\end{tabular}




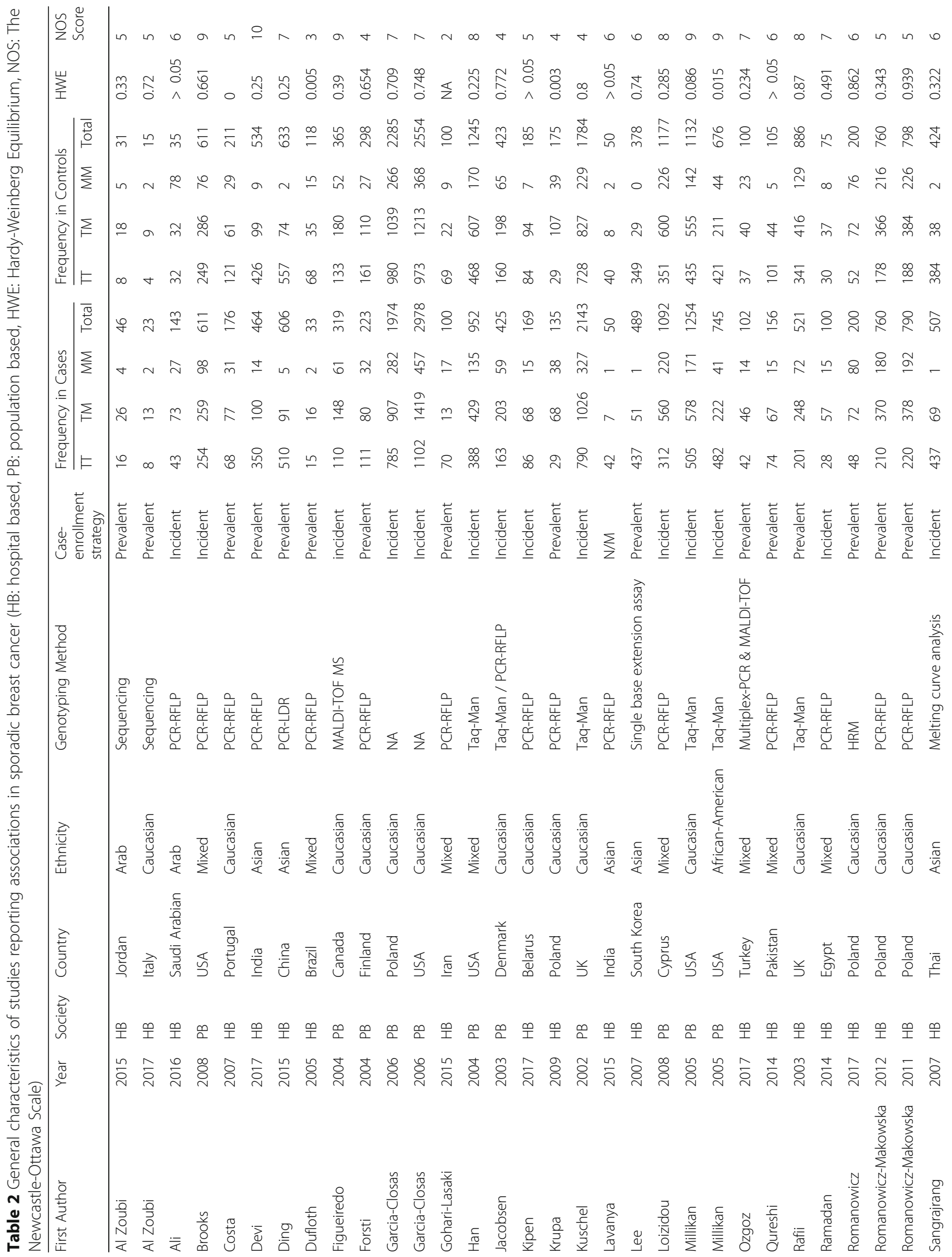




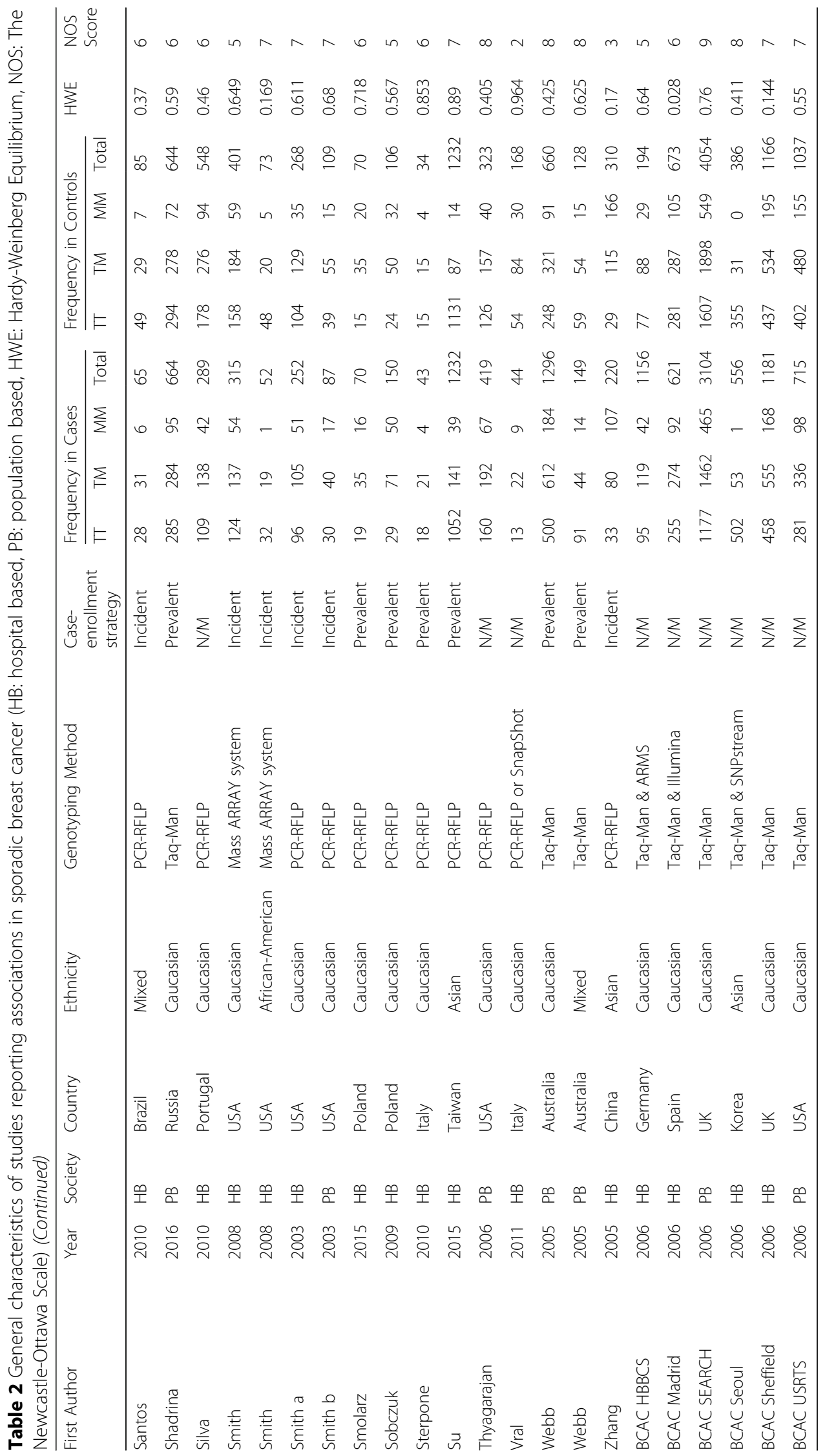


Table 3 Meta-analysis of studies reporting sporadic cases in different subgroups

\begin{tabular}{|c|c|c|c|c|c|c|c|}
\hline \multicolumn{2}{|l|}{ Potential } & $\begin{array}{l}\text { Odd Ratio } \\
\text { (Cl 95\%) }\end{array}$ & No of Studies & Heterogeneity $x^{2}$ & $P$ value & $1^{2}$ & Interaction $p$ value \\
\hline \multicolumn{8}{|c|}{ A Homozygote model: MM vs. TT } \\
\hline \multirow[t]{5}{*}{ Ethnicity } & Caucasian & $0.922(0.838-1.016)$ & 31 & 63.02 & 0.000 & $52.4 \%$ & 0.0001 \\
\hline & Asian & $0.725(0.345-1.522)$ & 8 & 18.89 & 0.009 & $62.9 \%$ & \\
\hline & African-American & $1.278(0.826-1.977)$ & 2 & 0.77 & 0.381 & $0.0 \%$ & \\
\hline & Arab & $3.649(2.029-6.563)$ & 2 & 0.26 & 0.609 & $0.0 \%$ & \\
\hline & Mixed & $0.889(0.694-1.140)$ & 10 & 16.49 & 0.009 & $45.4 \%$ & \\
\hline \multirow[t]{2}{*}{ Study-based } & Hospital-based & $0.979(0.825-1.162)$ & 36 & 81.66 & 0.000 & $57.1 \%$ & 0.655 \\
\hline & Population-based & $0.869(0.796-0.950)$ & 17 & 26.22 & 0.051 & $39.0 \%$ & \\
\hline \multirow[t]{3}{*}{ Methodological quality } & Good & $0.974(0.786-1.208)$ & 15 & 36.70 & 0.001 & $61.9 \%$ & 0.891 \\
\hline & Fair & $0.930(0.830-1.041)$ & 36 & 84.07 & 0.000 & $58.4 \%$ & \\
\hline & Poor & $0.644(0.338-1.229)$ & 2 & 0.37 & 0.544 & $0.0 \%$ & \\
\hline \multirow[t]{3}{*}{ Case enrollment strategies } & Incident & $0.938(0.819-1.075)$ & 20 & 54.88 & 0.000 & $59.9 \%$ & 0.455 \\
\hline & Prevalent & $0.887(0.720-1.093)$ & 23 & 45.70 & 0.001 & $58.4 \%$ & \\
\hline & Not mentioned & $0.975(0.798-1.191)$ & 10 & 21.53 & 0.011 & $58.2 \%$ & \\
\hline \multicolumn{2}{|l|}{ All studies } & $0.937(0.849-1.034)$ & 53 & 124.20 & 0.000 & $58.1 \%$ & - \\
\hline \multicolumn{8}{|c|}{ B Dominant model: TM + MM vs. TT } \\
\hline \multirow[t]{5}{*}{ Ethnicity } & Caucasian & $1.022(0.969-1.079)$ & 31 & 43.65 & 0.051 & $31.3 \%$ & 0.0001 \\
\hline & Asian & $1.296(1.027-1.636)$ & 8 & 18.22 & 0.011 & $61.6 \%$ & \\
\hline & African-American & $0.921(0.749-1.134)$ & 2 & 0.53 & 0.465 & $0.0 \%$ & \\
\hline & Arab & $0.671(0.419-1.074)$ & 2 & 0.00 & 0.950 & $0.0 \%$ & \\
\hline & Mixed & $1.084(0.863-1.361)$ & 10 & 33.91 & 0.000 & $73.5 \%$ & \\
\hline \multirow[t]{2}{*}{ Study-based } & Hospital-based & $1.089(0.975-1.215)$ & 36 & 89.81 & 0.000 & $61.0 \%$ & 0.655 \\
\hline & Population-based & $1.017(0.955-1.084)$ & 17 & 31.38 & 0.012 & $49.0 \%$ & \\
\hline \multirow[t]{3}{*}{ Methodological quality } & Good & $1.028(0.950-1.112)$ & 15 & 36.88 & 0.001 & $62.0 \%$ & 0.891 \\
\hline & Fair & $1.050(1.010-1.091)$ & 36 & 84.16 & 0.000 & $58.4 \%$ & \\
\hline & Poor & $1.022(0.643-1.624)$ & 2 & 0.12 & 0.725 & $0.0 \%$ & \\
\hline \multirow[t]{3}{*}{ Case enrollment strategies } & Incident & $1.011(0.934-1.095)$ & 20 & 37.53 & 0.007 & $49.4 \%$ & 0.455 \\
\hline & Prevalent & $1.111(0.958-1.289)$ & 23 & 74.40 & 0.000 & $70.4 \%$ & \\
\hline & Not mentioned & $1.042(0.975-1.113)$ & 10 & 7.89 & 0.545 & $0.0 \%$ & \\
\hline \multicolumn{2}{|l|}{ All studies } & $1.045(0.982-1.112)$ & 53 & 121.39 & 0.000 & $57.2 \%$ & - \\
\hline \multicolumn{8}{|c|}{ C Recessive model: MM vs. $T M+\pi$} \\
\hline \multirow[t]{5}{*}{ Ethnicity } & Caucasian & $0.921(0.849-1.000)$ & 31 & 56.42 & 0.002 & $46.8 \%$ & 0.000 \\
\hline & Asian & $0.688(0.374-1.266)$ & 8 & 15.51 & 0.030 & $54.9 \%$ & \\
\hline & African-American & $1.265(0.778-2.055)$ & 2 & 1.02 & 0.312 & $2.2 \%$ & \\
\hline & Arab & $3.649(2.029-6.563)$ & 2 & 1.55 & 0.213 & $35.4 \%$ & \\
\hline & Mixed & $0.895(0.728-1.101)$ & 10 & 13.93 & 0.125 & $35.4 \%$ & \\
\hline \multirow[t]{2}{*}{ Study-based } & Hospital-based & $0.989(0.844-1.159)$ & 36 & 90.43 & 0.000 & $61.3 \%$ & 0.00 \\
\hline & Population-based & $0.868(0.806-0.934)$ & 17 & 21.79 & 0.150 & $26.6 \%$ & \\
\hline \multirow[t]{3}{*}{ Methodological quality } & Good & $0.961(0.822-1.125)$ & 15 & 27.19 & 0.018 & $48.5 \%$ & 0.153 \\
\hline & Fair & $0.942(0.841-1.055)$ & 36 & 99.37 & 0.000 & $64.8 \%$ & \\
\hline & Poor & $0.645(0.355-1.173)$ & 2 & 0.84 & 0.359 & $0.0 \%$ & \\
\hline \multirow[t]{3}{*}{ Case enrollment strategies } & Incident & $0.950(0.823-1.097)$ & 20 & 63.03 & 0.000 & $69.9 \%$ & 0.377 \\
\hline & Prevalent & $0.900(0.761-1.064)$ & 23 & 45.19 & 0.003 & $51.3 \%$ & \\
\hline & Not mentioned & $0.974(0.812-1.168)$ & 10 & 21 & 0.013 & $57.1 \%$ & \\
\hline \multicolumn{2}{|l|}{ All studies } & $0.939(0.857-1.029)$ & 55 & 131.15 & 0.000 & $60.3 \%$ & - \\
\hline
\end{tabular}


Table 4 Meta-analysis of studies reporting familial cases in different subgroups

\begin{tabular}{|c|c|c|c|c|c|c|c|}
\hline \multicolumn{2}{|l|}{ Potential } & $\begin{array}{l}\text { Odd Ratio } \\
\text { (Cl 95\%) }\end{array}$ & No of Studies & Heterogeneity $x^{2}$ & $P$ value & $\mathrm{I}^{2}$ & $\begin{array}{l}\text { Interaction } \\
p \text { value }\end{array}$ \\
\hline \multicolumn{8}{|c|}{ A Homozygote model: MM vs. TT } \\
\hline \multirow[t]{2}{*}{ Ethnicity } & Caucasian & $1.204(0.835-1.735)$ & 5 & 2.56 & 0.634 & $0.0 \%$ & 0.000 \\
\hline & Mixed & $0.451(0.309-0.659)$ & 3 & 1.8 & 0.406 & $0.0 \%$ & \\
\hline \multirow[t]{2}{*}{ Study-based } & Hospital-based & $1.184(0.784-1.788)$ & 4 & 1.52 & 0.677 & $0.0 \%$ & 0.690 \\
\hline & Population-based & $0.581(0.318-1.060)$ & 4 & 8.24 & 0.041 & $63.6 \%$ & \\
\hline \multirow[t]{3}{*}{ Methodological quality } & Good & $1.080(0.691-1.688)$ & 3 & 0.67 & 0.716 & $0.0 \%$ & 0.002 \\
\hline & Fair & $0.504(0.304-0.834)$ & 4 & 4.51 & 0.211 & $33.5 \%$ & \\
\hline & Poor & $1.449(0.752-2.793)$ & 1 & 0.00 & & $\%$ & \\
\hline \multirow[t]{3}{*}{ Case enrollment strategies } & Incident & $1.000(0.300-3.327)$ & 2 & 1.64 & 0.201 & $38.9 \%$ & 0.068 \\
\hline & Prevalent & $0.683(0.412-1.134)$ & 5 & 10.69 & 0.030 & $62.6 \%$ & \\
\hline & Not mentioned & $1.449(0.752-2.793)$ & 1 & 0 & . & $\%$ & \\
\hline \multicolumn{2}{|l|}{ All studies } & $0.809(0.521-1.258)$ & 8 & 17.7 & 0.013 & $60.4 \%$ & - \\
\hline \multicolumn{8}{|c|}{ B Dominant model: TM + MM vs. $\Pi T$} \\
\hline \multirow[t]{2}{*}{ Ethnicity } & Caucasian & $1.012(0.800-1.280)$ & 5 & 0.82 & 0.936 & $0.0 \%$ & 0.576 \\
\hline & Mixed & $1.104(0.909-1.341)$ & 3 & 0.39 & 0.824 & $0.0 \%$ & \\
\hline \multirow[t]{2}{*}{ Study-based } & Hospital-based & $1.016(0.770-1.341)$ & 4 & 1.11 & 0.775 & $0.0 \%$ & 0.690 \\
\hline & Population-based & $1.087(0.910-1.299)$ & 4 & 0.25 & 0.969 & $0.0 \%$ & \\
\hline \multirow[t]{3}{*}{ Methodological quality } & Good & $1.132(0.855-1.499)$ & 3 & 0.13 & 0.937 & $0.0 \%$ & 0.614 \\
\hline & Fair & $1.075(0.887-1.304)$ & 4 & 0.41 & 0.937 & $0.0 \%$ & \\
\hline & Poor & $0.868(0.553-1.364)$ & 1 & 0.00 & . & $\%$ & \\
\hline \multirow[t]{3}{*}{ Case enrollment strategies } & Incident & $0.958(0.530-1.733)$ & 2 & 0.39 & 0.201 & $38.9 \%$ & 0.579 \\
\hline & Prevalent & $1.104(0.936-1.302)$ & 5 & 0.03 & 0.856 & $0.0 \%$ & \\
\hline & Not mentioned & $0.868(0.553-1.364)$ & 1 & 0 & . & $\%$ & \\
\hline \multicolumn{2}{|l|}{ All studies } & $1.066(0.917-1.238)$ & 8 & 1.52 & 0.982 & $0.0 \%$ & - \\
\hline \multicolumn{8}{|c|}{ C Recessive model: MM vs. TM $+\pi$} \\
\hline \multirow[t]{2}{*}{ Ethnicity } & Caucasian & $1.233(0.877-1.732)$ & 5 & 3.41 & 0.491 & $0.0 \%$ & 0.576 \\
\hline & Mixed & $0.462(0.298-0.716)$ & 3 & 2.65 & 0.266 & $24.5 \%$ & \\
\hline \multirow[t]{2}{*}{ Study-based } & Hospital-based & $1.224(0.834-1.796)$ & 4 & 1.25 & 0.742 & $0.0 \%$ & 0.690 \\
\hline & Population-based & $0.409(0.228-0.734)$ & 4 & 10.89 & 0.012 & $72.4 \%$ & \\
\hline \multirow[t]{3}{*}{ Methodological quality } & Good & $1.172(0.765-1.793)$ & 3 & 0.79 & 0.675 & $0.0 \%$ & 0.614 \\
\hline & Fair & $0.515(0.297-0.894)$ & 4 & 5.63 & 0.131 & $46.7 \%$ & \\
\hline & Poor & 1.389 (0.770-2.508) & 1 & 0.00 & .2 .508 & - & \\
\hline \multirow[t]{3}{*}{ Case enrollment strategies } & Incident & $0.977(0.258-3.707)$ & 5 & 14.05 & 0.007 & $71.5 \%$ & 0.579 \\
\hline & Prevalent & $0.718(0.410-1.257)$ & 2 & 2.36 & 0.124 & $57.7 \%$ & \\
\hline & Not mentioned & $1.389(0.770-2.508)$ & 1 & 0.00 & - & - & \\
\hline \multicolumn{2}{|l|}{ All studies } & $0.831(0.524-1.319)$ & 8 & 21.53 & 0.003 & $67.5 \%$ & - \\
\hline
\end{tabular}

Bold entry is significant

which did not intend to assess the association between XRCC3 Thr241Met SNP and breast cancer risk and those without control group data. Our participants are post- or pre-menopause women with breast cancer which is pathologically confirmed. Studies with male breast cancer cases were excluded. Our exposure is rs861539 (T241 M) that was evaluated with various genotyping methods such as PCR-RFLP, Taq-Man, Sequencing and etc. We performed search in the different mentioned sources and exported the search outputs into the End-Note software. The duplicated primary studies were deleted (only one version of the duplicated documents was kept). The screening phase (selecting included/ probable included versus excluded primary 


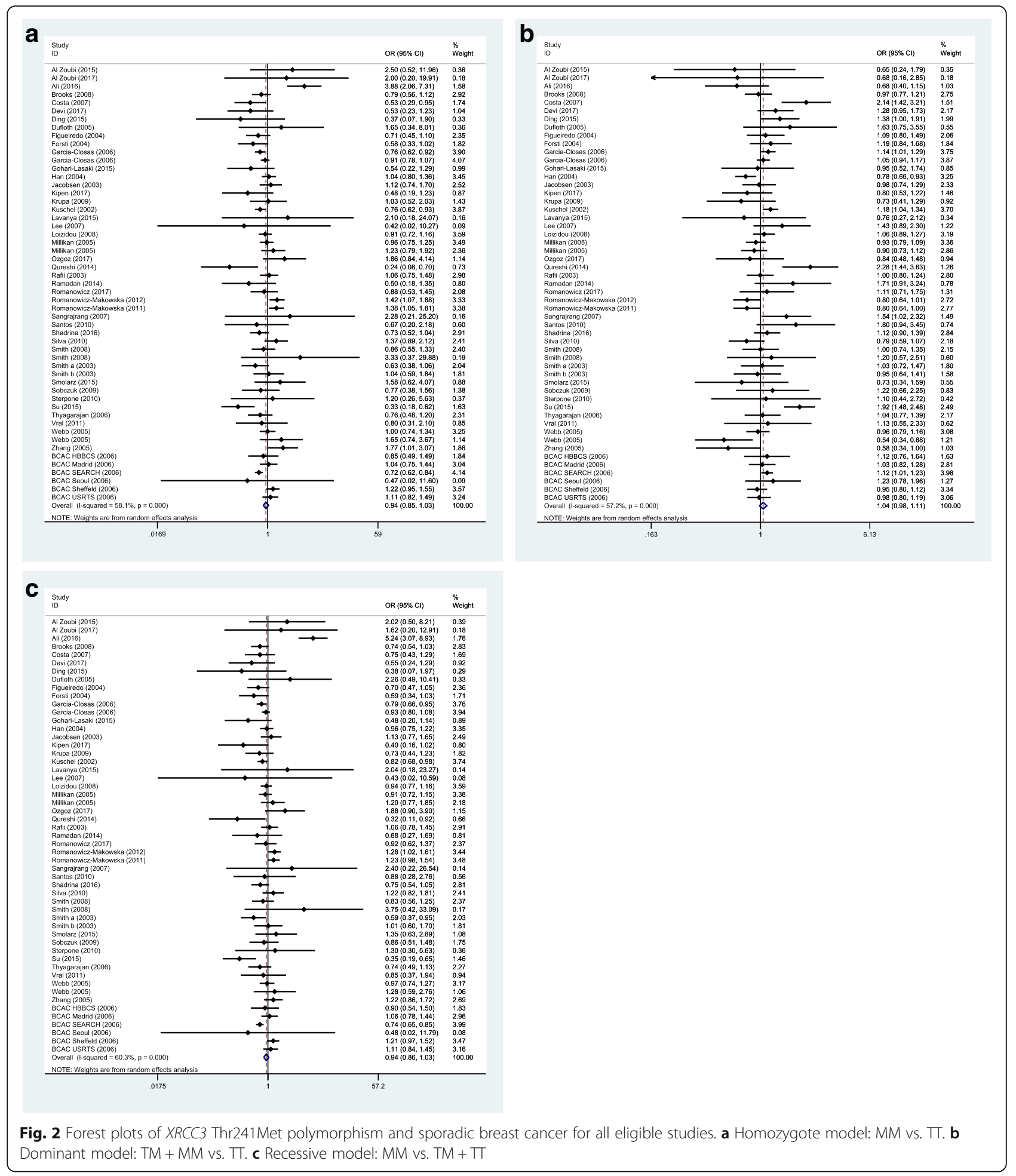

studies using the title or/ and the abstract) were performed. The selection or verification process (selecting included versus excluded primary studies) were performed based on the eligibility criteria. All steps for preparing this systematic review such as searching, screening based on titles of papers and abstracts, selection according to examination of full text of articles, risk of bias assessment and data extraction were done independently by two authors (SD and ZTE). Any disagreement regarding the inclusion/exclusion criteria and data extraction were resolved by consensus of the reviewers. 


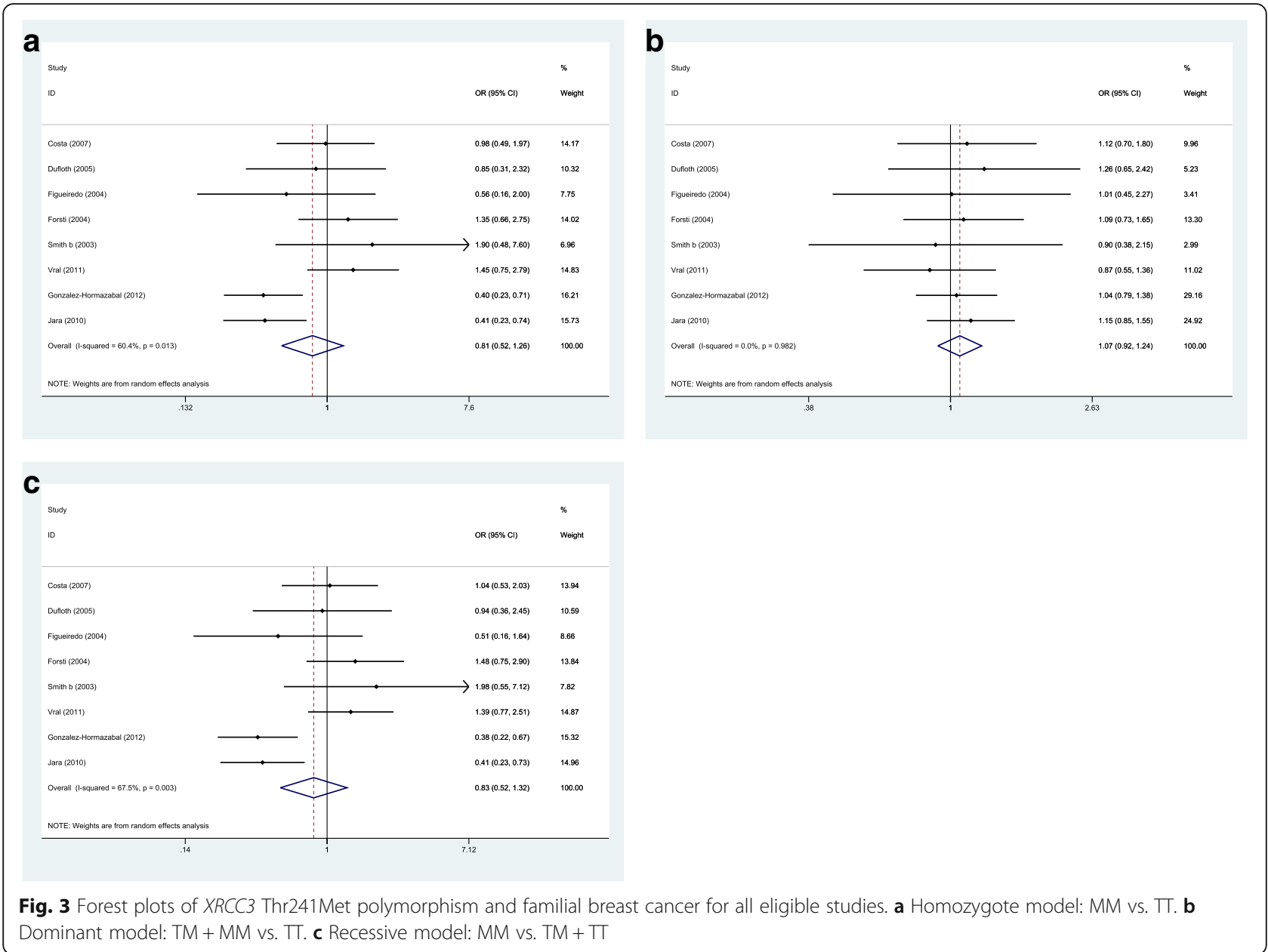

\section{Quality assessment and data extraction}

Methodological quality assessment (risk of bias assessment) was based on the Newcastle-Ottawa Scale (NOS). Checklist of each study was filled with two reviewers independently. Any disagreements (between two reviewers) were resolved by the discussion or consensus otherwise opinion of third expert reviewer. For assessing total quality status in primary study we used sum score of quality items. According to this score, we classified the papers in three groups (Good, Fair, Poor) [6]. Data was extracted by two reviewers as described above. Dataincluded general information of studies, study eligibility, method, risk of bias assessment and results including odds ratio. If there were some unclear information, we contacted with corresponding authors of studies. Our data extraction form includes the following items: First author, Publication year, Source of study participants, Name of Country, Ethnicity, Genotyping method and Reference number. Association between the mentioned polymorphism and breast cancer was evaluated by calculating crude OR based on 2-by-2 table. Furthermore, this association was assessed after controlling potentially confounder variables. For this reason, we extracted adjusted OR values which were calculated by logistic regression in primary studies. Since multi-variable logistic regression models in primary studies were not similar, all adjusted OR values were extracted from primary studies in order to combine similar adjusted OR values in data synthesis step.

\section{Data synthesis (meta-analysis)}

All of data analyses were performed in two distinct groups of familial breast cancer and sporadic breast cancer. Data were analyzed using STATA 13 software. Association between the mentioned SNP and breast cancer risk were analyzed by pooling odds ratio (ORs) with $95 \%$ confidence interval (CIs) in three models including dominant (TM + MM vs.TT), recessive (MM vs. $\mathrm{TM}+\mathrm{TT}$ ), and homozygote (MM vs.TT) models using STATA metan module. $Z$ test was applied to assess the significance of the ORs, The heterogeneity between included publications was evaluated using $\mathrm{I}^{2}$ parameter as described previously [14] where the 




Fig. 4 Forest plots of XRCC3 Thr241Met polymorphism and risk of sporadic breast cancer in ethnic-based subgroups. a Homozygote model: MM vs. TT. b Dominant model: TM + MM vs. TT. c Recessive model: MM vs. TM + TT 


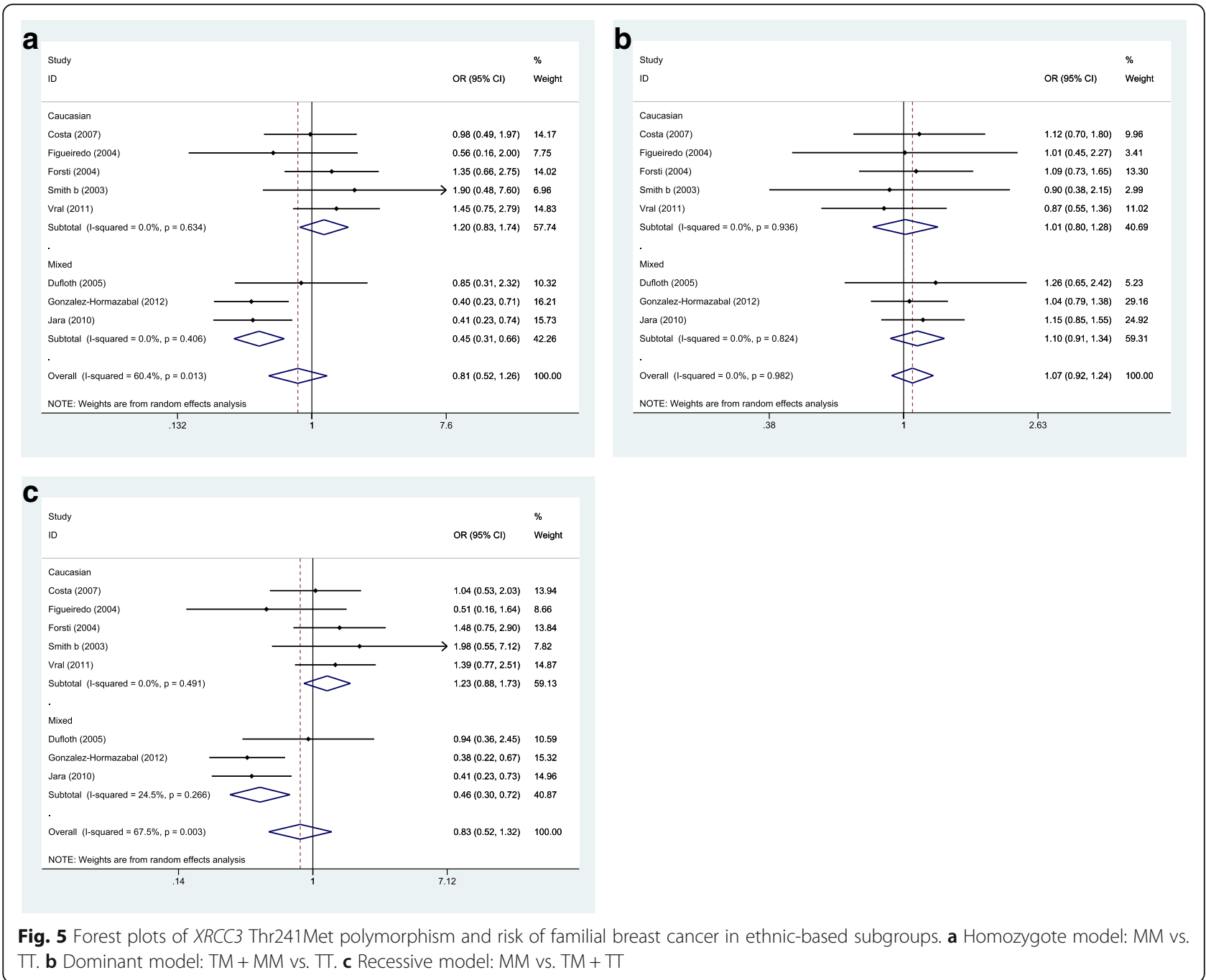

higher values indicate higher level of heterogeneity. Furthermore, we checked heterogeneity by the chisquare-based Q-test (Heterogeneity was considered statistically significant if $p<0.05$ ) (Egger et al., 1997). We combined genotype frequencies to calculate univariable (crude) OR. In addition, combination of adjusted OR values was based on the similarity of adjusted OR values restricted in two models including age-adjusted (association between rs861539 and breast cancer after controlling age of patients) and age and other factors. The random-effects model was used to combine parameters acquired from discrete studies due to methodological variation. Sensitivity analyses were performed using leave-one-out sensitivity analysis to indicate the effect of the quality score on the results. Subgroup analyses were done for evaluating potential sources of heterogeneity based on ethnicity, case selection methods case group (hospital vs. population), methodological quality status (Good, Fair, Poor) and-case enrollment strategies (incident vs. prevalent).

\section{Publication bias}

Funnel plots, Begg's and Egger's test were used to measure publication bias $(p$-value $<0.1)[6,11]$.

\section{Results}

\section{Literature search}

Figure 1 shows the data collection flow diagram for the present study. At the first step of database search, 4795 items were obtained. The initial screening and removal of duplicate items led to identification of 287 publications. Further screening resulted in removal of 187 items. Finally, full texts of the remained items were assessed for eligibility and 55 publications containing 30,966 sporadic breast cancer cases, 1174 familial breast cancer cases and 32,890 controls were included in the syntheses $[8,15-57]$. Tables 1 and 2 show the features of selected studies which assessed the association between the mentioned SNP and breast cancer in familial and sporadic cases respectively. 

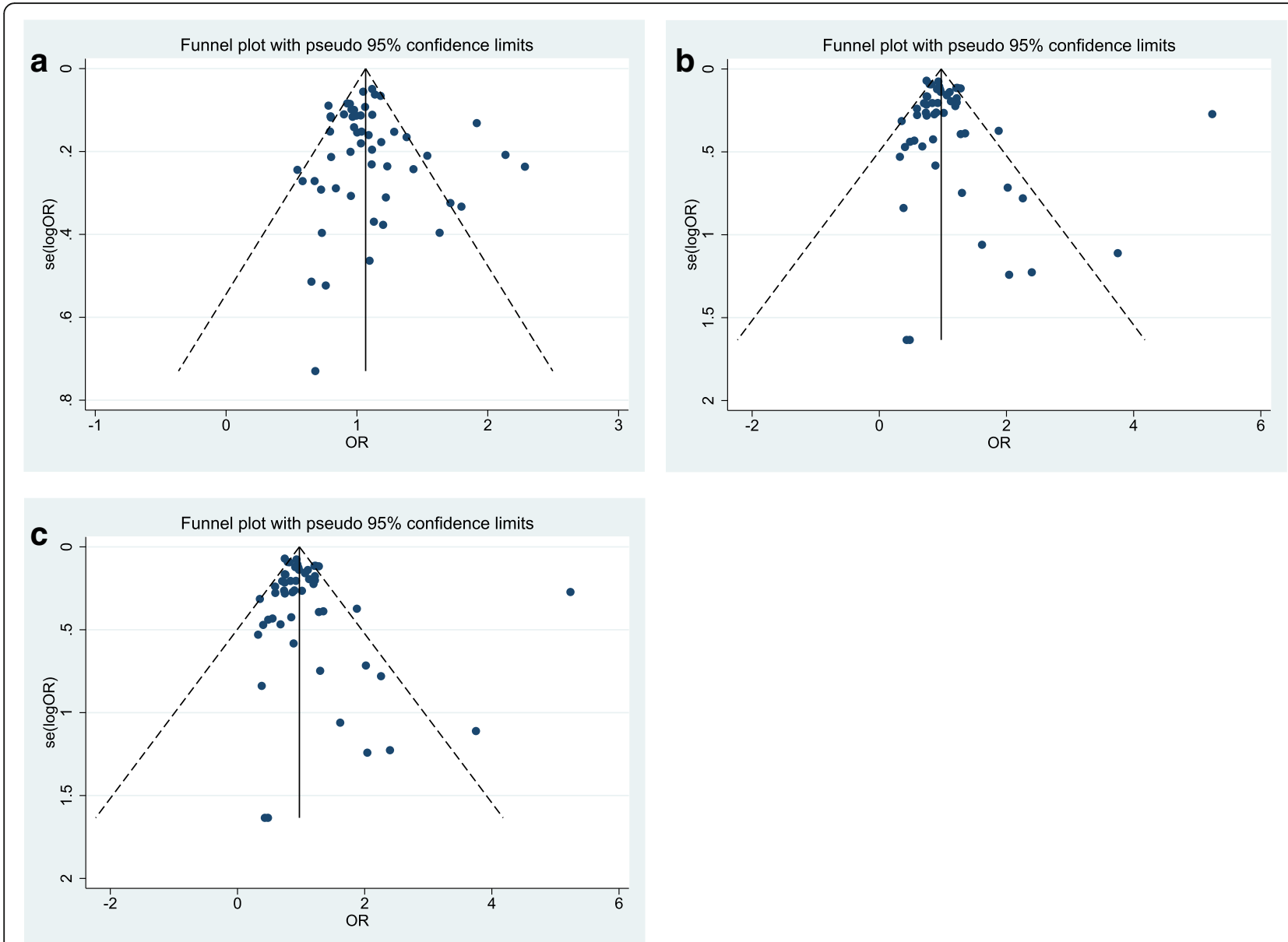

Fig. 6 Funnel plots for whole publications in sporadic cases. a Dominant model: TM + MM vs.TT. b Recessive model: MM vs. TM+ TT. c Homozygote model: MM vs.TT

\section{Meta-analysis results}

Initially, we conducted the analysis in the familial and sporadic studies after using the random-effects model. Random model was used for analysis of associations in three inheritance models based on its more conservative nature. Final results for familial and sporadic studies are shown in Tables 3 and 4.

The forest plots for each model are depicted in Figs. 2 and 3 .

No significant associations were detected between the mentioned SNP and breast cancer risk in any inheritance model either in familial or in sporadic breast cancer cases.

Next, we assessed association between this SNP and risk of familial or sporadic breast cancer in ethnic-based subgroups (Figs. 4 and 5). In sporadic breast cancer, the SNP was associated with breast cancer risk in Arab populations in homozygous (OR $(95 \% \quad \mathrm{CI})=3.649$ (2.029-6.563), $p=0.0001$ ) and recessive models (OR $(95 \%$ CI $)=4.092(1.806-9.271), p=0.001)$. However, the association was significant in Asian population in dominant model $(\mathrm{OR}(95 \% \mathrm{CI})=1.296(1.027-1.636)$, $p=0.029)$. Based on the calculated Interaction $p$-value in ethnic-based subgroup analyses $(p=0.0001)$, we conclude that such subgroup analysis strategy was appropriate and the calculated ORs are significant. However, the associations was significant in familial breast cancer in mixed ethnic-based subgroup in homozygote and recessive models (OR (95\% CI) $=0.451 \quad(0.309-0.659)$, $p=0.0001$, OR $(95 \% \mathrm{CI})=0.462(0.298-0.716), p=$ 0.001 respectively).

Subsequently, we appraised the associations based on the study-base for selecting case/control (society) subgroup (hospital-based vs. population-based). In sporadic cases, the associations were significant in populationbased studies in homozygote and recessive models (OR $(95 \% \mathrm{CI})=0.869(0.796-0.950), p=0.002$ and OR $(95 \%$ CI $=0.868$ (0.806-0.934), $p=0.0001$ respectively). The Interaction $p$-value was calculated as 0.655 which shows inappropriateness of such subgroup analysis strategy. No significant associations were found in society-based analysis in familial cases (Additional file 2: Figure S1 and Additional file 3: Figure S2). 

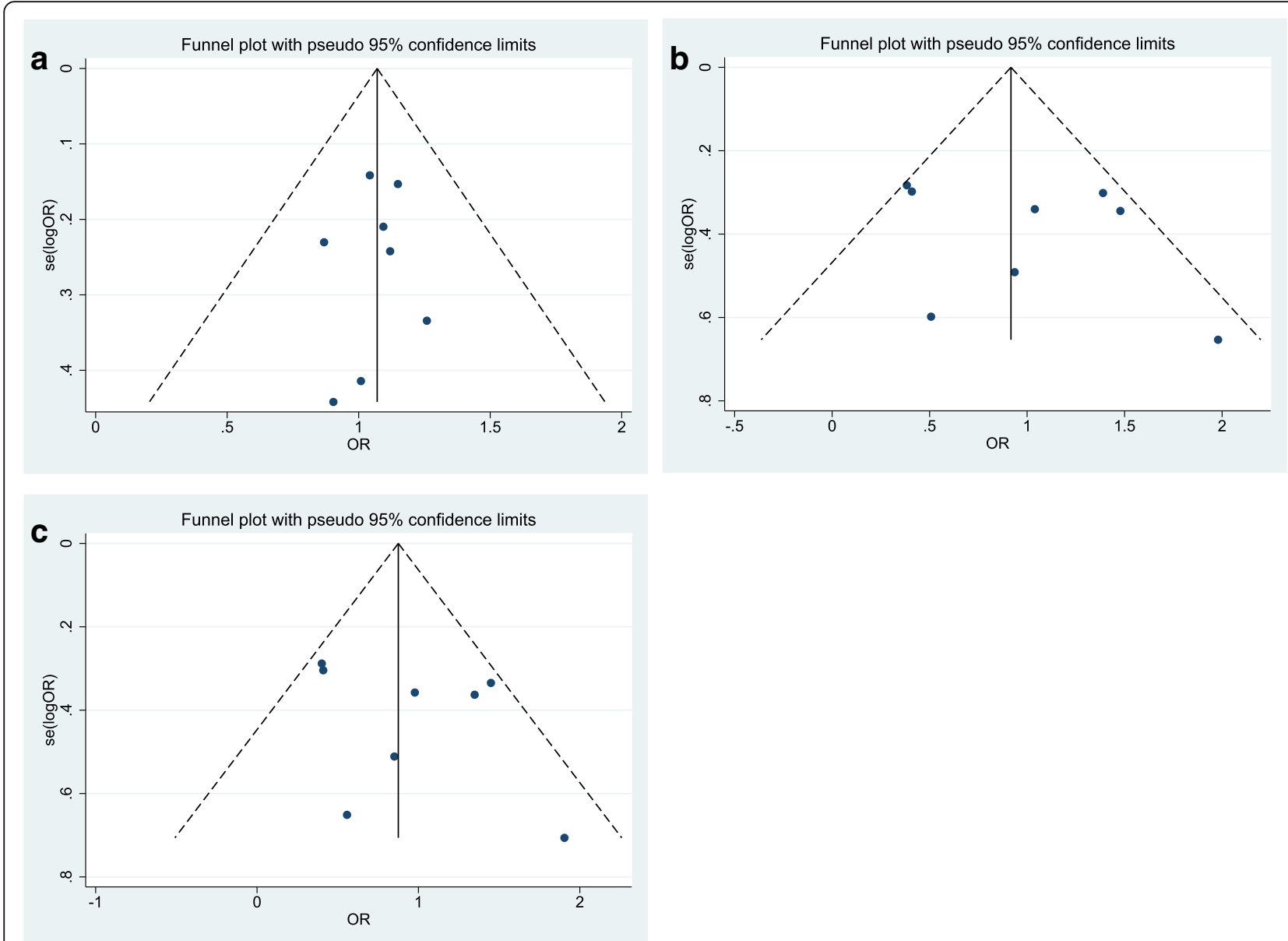

Fig. 7 Funnel plots for whole publications in familial cases. a Dominant model: $T M+M M$ vs.TT. b Recessive model: MM vs. TM + TT. c Homozygote model: MM vs.TT

We also assessed the associations in methodological quality subgroups (Based on NOS scores) and found no significant association in sporadic (Interaction $p$-value $=0.891$ ) but in familial cases we found the association in studies with fair quality in homozygote and recessive models (OR $(95 \% \mathrm{CI})=0.504(0.304-0.834), p=0.008, \mathrm{OR}(95 \% \mathrm{CI})=$ $0.515(0.297-0.894), p=0.018$ respectively) (Additional file 4: Figure S3 and Additional file 5: Figure S4).

Finally, we evaluated associations based on the case enrollment strategy (Incident vs. Prevalent). No significant associations were detected either in sporadic or familial cases (Interaction p-value $=0.22$ ) (Additional file 6: Figure S5 and Additional file 7: Figure S6).

\section{Publication bias}

We conducted both Begg's funnel plot and Egger's test for appraisal of the publication bias in sporadic and familial studies separately. The calculated parameters are shown in Tables 3 and 4. Moreover, the outlines of the funnel plots were rather symmetric implying absence of any significant publication bias (Figs. 6 and 7).

\section{Adjusted OR}

As we did not detected any association between the mentioned SNP and breast cancer risk in crude analysis, we subsequently assessed associations considering the effects of confounder variables using adjusted ORs. We retrieved adjusted ORs and confounder variables from the publications. Subsequently, we categorized confounder variables to two groups: 1. Age 2. Other variables including body mass index, smoking, hazardous life style and contraceptive use. Analyses were performed in sporadic subgroup based on the three inheritance models (Fig. 8). There was no significant association between this SNP and risk of sporadic breast cancer in any inheritance model considering adjusted ORs.

\section{Sensitivity analysis and cumulative meta-analysis}

To assess the strength of the association results, we conducted a leave-one-out sensitivity analysis by repeatedly removing one study at a time and re-measuring the summary OR. The summary ORs did not change, 


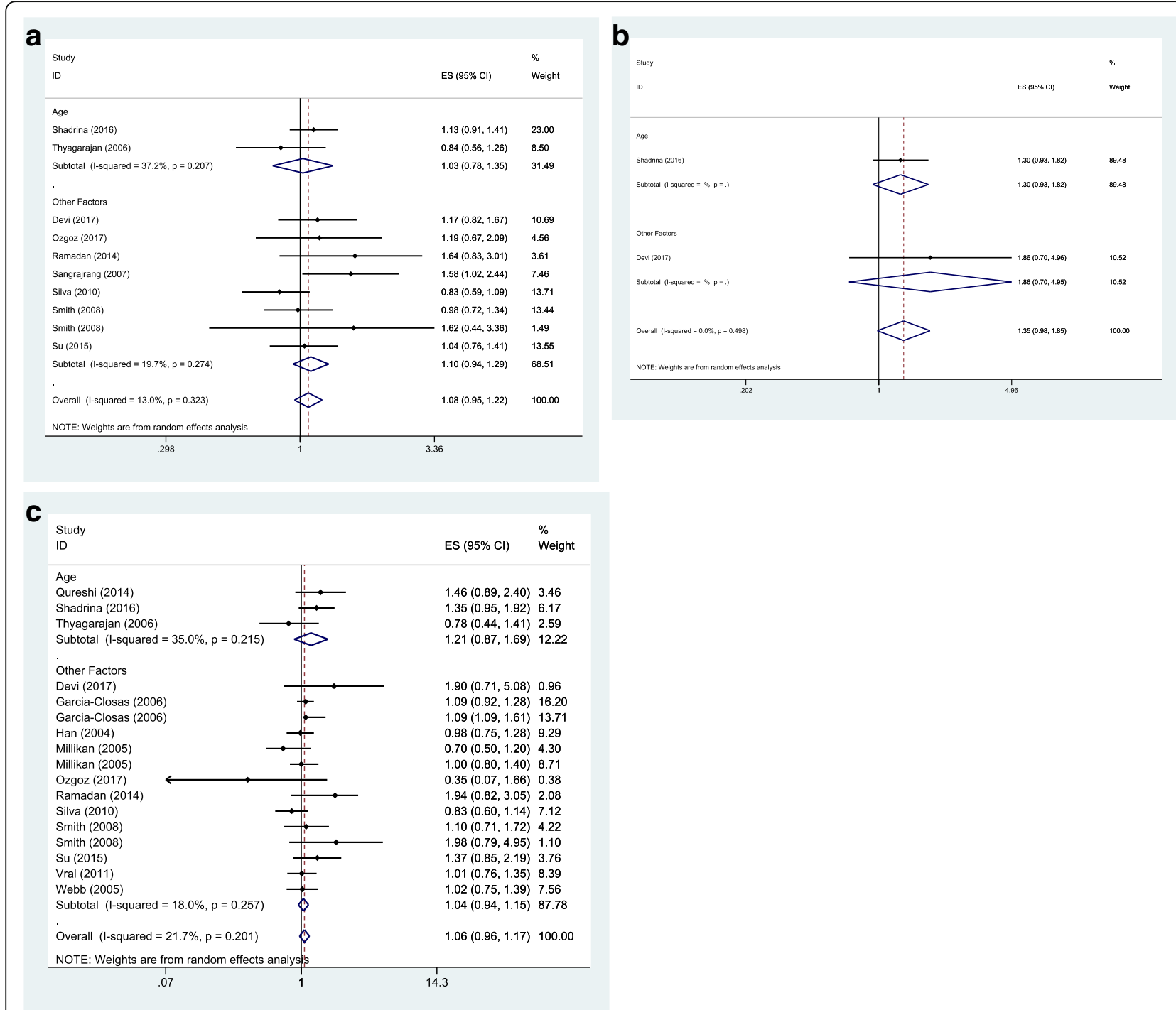

Fig. 8 Forest plots for adjusted OR (adjusted for Age and Other variables including body mass index, smoking, hazardous life style and contraceptive use.) in sporadic cases. a Dominant model: TM + MM vs.TT. b Recessive model: MM vs. TM + TT. c Homozygote model: MM vs.TT

showing that our results were not originated from any certain study (Table 1 ).

\section{Discussion}

In the present meta-analysis, we assessed the associations between Thr241Met SNP and familial/ sporadic breast cancer based on the results of 55 studies containing 30,966 sporadic breast cancer cases, 1174 familial breast cancer cases and 32,890 controls. Crude analyses revealed no associations. In spite of assessing potential confounder variables and adjusting odds ratio of the primary studies, we did not find any association.

In sporadic cases, the narrow confidence intervals indicate the high power of the meta-analysis, so the results are conclusive. However, in familial cases, the wide confidence intervals imply that further studies are needed to reach conclusive results. Based on such findings, we predict that inclusion of further studies would not change the results of the meta-analysis. Sensitivity analyses by repeatedly removing one study at a time showed that the results of crude analysis were consistent result, therefore signifying the robustness of the study according to sensitivity analysis results, no relation between quality of studies with results and non-considerable publication bias.

Another strong point of our study was that we considered adjusted ORs to control the effects of confounding variables. Such approach further verified our results.

Through calculation of Interaction $p$ values we determined subgroup analysis based on ethnicity as being the most strategy in this regard. Ethnic based analysis showed that in sporadic breast cancer, the SNP was 
associated with breast cancer risk in Arab and Mixed populations in homozygous and recessive models. The association was significant in Asian population in dominant model. However, no associations were detected in familial breast cancer in any ethnic-based subgroup and any inheritance model. The detected associations between this SNP and risk of sporadic breast cancer in certain populations had wide confidence intervals which necessitate extra studies. The same situation has been seen in familial breast cancer cases in ethnic-based subgroup analyses.

Chai et al. have performed a meta-analysis of 23 casecontrols studies on association between Thr241Met SNP and breast cancer. Their meta-analysis of the pooled data of 13,513 cases and 14,100 controls association between the mentioned SNP and breast cancer risk in recessive and homozygote models in total populations as well as within Asian populations [14]. Our study had the advantage of including higher numbers of cases and controls and assessment of adjusted ORs and sensitivity analysis. The results of our ethnic-based analysis were consistent with their results regarding the observed association in Asian population but not regarding the associated model. Although they found association between this SNP and risk of sporadic breast cancer, we disapprove such association based on the obtained conclusive results.

In brief, we have implemented the high quality systematic review and meta-analysis including comprehensiveness (inclusion of 5 databases), inclusion of grey literature (theses) and duplicate implementation of all steps of systematic review and meta-analysis (independent implementation of search, screening, selection, quality assessment and data extraction by two authors). In addition, priori principle (establishment and registration of protocol) was applied.

Our study had some limitations. Based on the unavailability of sufficient data from the primary studies, we could not assess the association between the mentioned SNP and breast cancer risk in pre-/post-menopause subgroups. In addition, the adjusted OR values of the primary studies were based on different parameters which might influence the validity of this kind of statistical analysis. Finally, there were some limitations in the primary studies and we did not find any genotyping data according to breast cancer subtypes except for 3 studies in triple negative breast cancer. Due to the low number of primary studies, the result of meta-analysis based on breast cancer subtypes was not reliable. So, we did not performed this type of analysis.

\section{Conclusion}

Taken together, our results in a large sample of both sporadic and familial cases of breast cancer showed insignificant role of Thr241Met in the pathogenesis of this type of malignancy. Such results were more conclusive in sporadic cases. In familial cases, future studies are needed to verify our results.

\section{Additional files}

Additional file 1: The search syntaxes for each database. (DOCX 14 kb)

Additional file 2: Figure S1. Forest plots of XRCC3 Thr241Met polymorphism and risk of sporadic breast cancer in Study-based subgroups. (D) Homozygote model: MM vs. TT. (E) Dominant model: TM + MM vs. TT. (F) Recessive model: MM vs. TM + T. (ZIP 21 kb)

Additional file 3: Figure S2. Forest plots of XRCC3 Thr241Met polymorphism and risk of familial breast cancer in society -based subgroups. (D) Homozygote model: MM vs. TT. (E) Dominant model: TM + MM vs. TT. (F) Recessive model: MM vs. TM + TT. (ZIP 8 kb)

Additional file 4: Figure S3. Forest plots of XRCC3 T241 M Polymorphism and Sporadic Breast Cancer according to NOS subgroup analysis. (A) Homozygote model: MM vs. TT. (B) Dominant model: TM + MM vs. T. (C) Recessive model: MM vs. TM + T. (ZIP 22 kb)

Additional file 5: Figure S4. Forest plots of XRCC3 T241 M Polymorphism and Familial Breast Cancer according to NOS subgroup analysis. (A) Homozygote model: MM vs. TT. (B) Dominant model: TM + MM vs. TT. (C) Recessive model: MM vs. TM + T. (ZIP 9 kb)

Additional file 6: Figure S5. Forest plots of XRCC3 T241 M Polymorphism and Sporadic Breast Cancer according to case enrollment subgroup analysis. (A) Homozygote model: MM vs. TT. (B) Dominant model: TM + MM vs. TT. (C) Recessive model: MM vs. TM + TT. (ZIP 22 kb)

Additional file 7: Figure S6. Forest plots of XRCC3 T241 M Polymorphism and Familial Breast Cancer according to case enrollment subgroup analysis. (A) Homozygote model: MM vs. TT. (B) Dominant model: TM + MM vs. TT. (C) Recessive model: MM vs. TM + TT. (ZIP 9 kb)

\section{Abbreviations}

Cls: 95\% confidence intervals; DSB: DNA double strand break; HB: Hospital based; HR: Homologous recombination; HWE: Hardy-Weinberg Equilibrium; NHEJ: Non-homologous end-joining; NOS: Newcastle-Ottawa Scale; ORs: Crude odds ratios; PB: Population based; SNP: Single-nucleotide polymorphism; XRCC3: X-ray repair cross-complementing group 3

\section{Acknowledgements}

The authors declare that there is no conflict of interest.

\section{Funding}

Not applicable.

Availability of data and materials

All data generated or analysed during this study are included in this published article and its supplementary information files.

\section{Authors' contributions}

SD and ZTE assessed the studies and performed the meta-analysis. AK and SGF supervised the study. AK contributed in data acquisition and analysis. SGF wrote the manuscript. All authors approved the manuscript.

\section{Ethics approval and consent to participate}

Not applicable.

\section{Consent for publication}

Not applicable.

Competing interests

The authors declare that they have no competing interests.

\section{Publisher's Note}

Springer Nature remains neutral with regard to jurisdictional claims in published maps and institutional affiliations.

\section{Author details}

${ }^{1}$ Department of Medical Genetics, Shahid Beheshti University of Medical Sciences, Tehran, Iran. ${ }^{2}$ Department of Health Sciences Education 
Development, School of Public Health, Tehran University of Medical Sciences, Tehran, Iran

\section{Received: 25 February 2019 Accepted: 16 April 2019 Published online: 10 May 2019}

\section{References}

1. Siegel RL, Miller KD, Jemal A. Cancer statistics, 2017. CA Cancer J Clin. 2017; 67(1):7-30 PubMed PMID: 28055103. Epub 2017/01/06. eng.

2. Davis AJ, Chen DJ. DNA double strand break repair via non-homologous end-joining. Translational Cancer Res. 2013;2:130.

3. Bau DT, Mau YC, Ding SL, Wu PE, Shen CY. DNA double-strand break repair capacity and risk of breast cancer. Carcinogenesis. 2007;28(8):1726-30 PubMed PMID: 17494053. Epub 2007/05/12. eng.

4. den Brok WD, Schrader KA, Sun S, Tinker AV, Zhao EY, Aparicio S, et al. Homologous recombination deficiency in breast Cancer: a clinical review. JCO Precision Oncology. 2017;1:1-13.

5. Brenneman MA, Weiss AE, Nickoloff JA, Chen DJ. XRCC3 is required for efficient repair of chromosome breaks by homologous recombination. Mutat Res. 2000; 459(2):89-97 PubMed PMID: 10725659. Epub 2000/03/22. eng.

6. Han S, Zhang H-T, Wang Z, Xie Y, Tang R, Mao Y, et al. DNA repair gene XRCC3 polymorphisms and cancer risk: a meta-analysis of 48 case-control studies. Eur J Hum Genet. 2006;14(10):1136.

7. García-Closas M, Egan KM, Newcomb PA, Brinton LA, Titus-Ernstoff L, Chanock $S$, et al. Polymorphisms in DNA double-strand break repair genes and risk of breast cancer: two population-based studies in USA and Poland, and meta-analyses. Hum Genet. 2006;119(4):376.

8. Lee S-A, Lee K-M, Park SK, Choi J-Y, Kim B, Nam J, et al. Genetic polymorphism of XRCC3 Thr 241 met and breast cancer risk: case-control study in Korean women and meta-analysis of 12 studies. Breast Cancer Res Treat. 2007;103(1):71-6.

9. Economopoulos KP, Sergentanis TN. XRCC3 Thr241Met polymorphism and breast cancer risk: a meta-analysis. Breast Cancer Res Treat. 2010;121(2):439-43.

10. He X-F, Wei W, Su J, Yang Z-X, Liu Y, Zhang Y, et al. Association between the XRCC3 polymorphisms and breast cancer risk: meta-analysis based on case-control studies. Mol Biol Rep. 2012;39(5):5125-34.

11. He X-F, Wei W, Li J-L, Shen X-L, D-p D, Wang S-L, et al. Association between the XRCC3 T241M polymorphism and risk of cancer: evidence from 157 case-control studies. Gene. 2013;523(1):10-9.

12. Mao C-F, Qian W-Y, Wu J-Z, Sun D-W, Tang J-H. Association between the XRCC3 Thr241Met polymorphism and breast cancer risk: an updated meta-analysis of 36 case-control studies. Asian Pac J Cancer Prev. 2014;15(16):6613-8.

13. Fan Chai $Y L$, Chen L, Zhang F, Jiang J. Association between XRCC3 Thr241Met polymorphism and risk of breast cancer: meta-analysis of 23 case-control studies. Med Sci Monit. 2015;21:3231.

14. Chai F, Liang Y, Chen L, Zhang F, Jiang J. Association Between XRCC3 Thr241Met Polymorphism and Risk of Breast Cancer: Meta-Analysis of 23 Case-Control Studies. Med Sci Monitor. 2015;21:3231-40 PubMed PMID; WOS:000363690300001. English.

15. Al Zoubi MS. X-ray repair cross-complementing protein 1 and 3 polymorphisms and susceptibility of breast cancer in a Jordanian population. Saudi Med J. 2015;36(10):1163-7 PubMed PMID: WOS: 000366141300004

16. Brooks J, Shore RE, Zeleniuch-Jacquotte A, Currie D, Afanasyeva Y, Koenig KL, et al. Polymorphisms in RAD51, XRCC2, and XRCC3 are not related to breast cancer risk. Cancer Epidemiol Biomarkers Prev. 2008; 17(4):1016-9 English.

17. Costa S, Pinto D, Pereira D, Rodrigues H, Cameselle-Teijeiro J, Medeiros R, et al. DNA repair polymorphisms might contribute differentially on familial and sporadic breast cancer susceptibility: a study on a Portuguese population. Breast Cancer Res Treat. 2007;103(2):209-17 PubMed PMID: WOS:000246611000008.

18. Devi KR, Ahmed J, Narain K, Mukherjee K, Majumdar G, Chenkual S, et al. DNA repair mechanism gene, XRCC1A (Arg194Trp) but not XRCC3 (Thr241Met) polymorphism increased the risk of breast Cancer in premenopausal females: a Case-control study in northeastern Region of India. Technol Cancer Res Treat. 2017;16(6):1150-9.

19. Ding PJ, Yang Y, Cheng LY, Zhang XJ, Cheng LM, Li CZ, et al. The Relationship between Seven Common Polymorphisms from Five DNA
Repair Genes and the Risk for Breast Cancer in Northern Chinese Women. Plos One. 2014:9(3):e92083. PubMed PMID: WOS:000333259900080.

20. Dufloth RM, Costa S, Schmitt F, Zeferino LC. DNA repair gene polymorphisms and susceptibility to familial breast cancer in a group of patients from Campinas, Brazil. Genet Mol Res. 2005;4(4):771-82.

21. Figueiredo JC, Knight JA, Briollais L, Andrulis IL, Ozcelik H. Polymorphisms XRCC1-R399Q and XRCC3-T241M and the risk of breast cancer at the Ontario Site of the Breast Cancer Family Registry. Cancer Epidemiol Biomarkers Prev. 2004;13(4):583-91 PubMed PMID: WOS: 000220724400013.

22. Forsti A, Angelini S, Festa F, Sanyal S, Zhang ZZ, Grzybowska EWA, et al. Single nucleotide polymorphisms in breast cancer. Oncology Reports. 2004; 11(4):917-22 PubMed PMID: WOS:000220172400030.

23. Gohari-Lasaki S, Gharesouran J, Ghojazadeh M, Montazeri V, Saadatian H, Ardebili SMM. Dna repair gene xrcc3 241 met variant and breast cancer susceptibility of azeri populationin Iranian. Genetika-Belgrade. 2015;47(2): 733-9 PubMed PMID: WOS:000363055800031.

24. Han J, Hankinson SE, Ranu H, De Vivo I, Hunter DJ. Polymorphisms in DNA double-strand break repair genes and breast cancer risk in the Nurses' health study. Carcinogenesis. 2004;25(2):189-95.

25. Jacobsen NR, Nexø BA, Olsen A, Overvad K, Wallin H, Tiønneland A, et al. No association between the DNA repair gene XRCC3 T241M polymorphism and risk of skin cancer and breast cancer. Cancer Epidemiol Biomarkers Prev. 2003;12(6):584

26. Kipen VN, Melnov SB, Smolyakova RM. The role of the XRCC1, XRCC3, and PALB2 genes in the genesis of sporadic breast cancer. Russ $J$ Genet. 2017;7(6):705-11.

27. Krupa R, Synowiec E, Pawlowska E, Morawiec Z, Sobczuk A, Zadrozny M, et al. Polymorphism of the homologous recombination repair genes RAD51 and XRCC3 in breast cancer. Exp Mol Pathol. 2009;87(1):32-5 PubMed PMID: WOS:000268156700005.

28. Kuschel B, Auranen A, McBride S, Novik KL, Antoniou A, Lipscombe JM, et al. Variants in DNA double-strand break repair genes and breast cancer susceptibility. Hum Mol Genet. 2002;11(12):1399 PubMed PMID: 211311954. English.

29. Lavanya J, Vijayakumar J, Sudhakar N, Prathap S. Analysis of DNA repair genetic polymorphism in breast cancer population. Int J Pharm Bio Sci. 2015;6(3):B966-B73.

30. Loizidou MA, Michael T, Neuhausen SL, Newbold RF, Marcou Y, Kakouri E, et al. Genetic polymorphisms in the DNA repair genes XRCC1, XRCC2 and XRCC3 and risk of breast cancer in Cyprus. Breast Cancer Res Treat. 2008; 112(3):575-9 PubMed PMID: WOS:000261951000020.

31. Millikan RC, Player JS, de Cotret AR, Tse CK, Keku T. Polymorphisms in DNA repair genes, medical exposure to ionizing radiation, and breast cancer risk. Cancer Epidemiol Biomarkers Prev. 2005;14(10):2326-34 PubMed PMID: WOS:000232473400008.

32. Özgöz A, Hekimler Öztürk K, Yükseltürk A, Şamlı H, Başkan Z, Mutlu İçduygu $F$, et al. Genetic variations of DNA repair genes in breast Cancer. Pathol Oncol Res. 2017:25(1):107-14.

33. Qureshi Z, Mahjabeen I, Baig RM, Kayani MA. Correlation between selected XRCC2, XRCC3 and RAD51 gene polymorphisms and primary breast Cancer in women in Pakistan. Asian Pac J Cancer Prev. 2014;15(23):10225-9 PubMed PMID: WOS:000351058400029.

34. Rafii SS. The role of variants of homologous recombination repair genes in breast cancer susceptibility and dna repair [Ph.D.]. Ann Arbor: University of Sheffield (United Kingdom); 2003.

35. Ramadan RA, Desouky LM, Elnaggar MA, Moaaz M, Elsherif AM. Association of DNA repair genes XRCC1 (Arg399GIn), (Arg194Trp) and XRCC3 (Thr241Met) polymorphisms with the risk of breast Cancer: a Case-control study in Egypt. Genet Test Mol Biomarkers. 2014;18(11):754-60 PubMed PMID: WOS:000344058900007.

36. Romanowicz H, Pyziak U, Jaboski F, Bry M, Forma E, Smolarz B. Analysis of DNA Repair Genes Polymorphisms in Breast Cancer. Pathol Oncol Res. 2017; 23(1):117-23 PubMed PMID: 1858236078. English.

37. Romanowicz-Makowska H, Brys M, Forma E, Maciejczyk R, Polac I, Samulak $D$, et al. Single nucleotide polymorphism (snp) thr241met in the xrcc3 gene and breast cancer risk in polish women. Pol J Pathol. 2012;63(2):121-5 PubMed PMID: WOS:000307373500006.

38. Romanowicz-Makowska H, Smolarz B, Zadrozny M, Westfa B, Baszczynski J, Kokolaszwili $\mathrm{G}$, et al. The association between polymorphisms of the RAD51-G135C, XRCC2-Arg188His and XRCC3-Thr241Met genes and clinico- 
pathologic features in breast cancer in Poland. Eur J Gynaecol Oncol. 2012 33(2):145-50 PubMed PMID: 22611952. Epub 2012/05/23. eng.

39. Romanowicz-Makowska H, Smolarz B, Polać I, Sporny S. Single nucleotide polymorphisms of RAD51 G135C, XRCC2 Arg188His and XRCC3 Thr241Met homologous recombination repair genes and the risk of sporadic endometrial cancer in Polish womenjog. J Obstet Gynaecol Res. 2012;38(6):918-24.

40. Romanowicz-Makowska H, Smolarz B, Zadrozny M, Westfal B, Baszczynski J, Polac I, et al. Single nucleotide polymorphisms in the homologous recombination repair genes and breast Cancer risk in Polish women. Tohoku J Exp Med. 2011;224(3):201-8 PubMed PMID: WOS: 000292573400006

41. Sangrajrang $S$, Schmezer $P$, Burkholder I, Boffetta P, Brennan P, Woelfelschneider A, et al. The XRCC3 Thr241Met polymorphism and breast cancer risk: a case-control study in a Thai population. Biomarkers. 2007;12(5):523-32 PubMed PMID: WOS:000248788700006.

42. Santos RA, Teixeira AC, Mayorano MB, Carrara HHA, Andrade JM, Takahashi CS. DNA repair genes XRCC1 and XRCC3 polymorphisms and their relationship with the level of micronuclei in breast cancer patients. Genet Mol Biol. 2010;33(4):637-40 PubMed PMID: WOS:000286321000007.

43. Shadrina AS, Ermolenko NA, Boyarskikh UA, Sinkina TV, Lazarev AF, Petrova VD, et al. Polymorphisms in DNA repair genes and breast cancer risk in Russian population: a case-control study. Clin Exp Med. 2016;16(1):21-8 PubMed PMID: WOS:000370156200003.

44. Silva SN, Tomar M, Paulo C, Gomes BC, Azevedo AP, Teixeira V, et al. Breast cancer risk and common single nucleotide polymorphisms in homologous recombination DNA repair pathway genes XRCC2, XRCC3, NBS1 and RAD51. Cancer Epidemiol. 2010;34(1):85-92 PubMed PMID: WOS:000276270400016.

45. Smith TR, Levine EA, Freimanis RI, Akman SA, Allen GO, Hoang KN, et al. Polygenic model of DNA repair genetic polymorphisms in human breast cancer risk. Carcinogenesis. 2008;29(11):2132-8 PubMed PMID: WOS: 000260977900012

46. Smith TR, Miller MS, Lohman K, Lange EM, Case LD, Mohrenweiser HW, et al. Polymorphisms of XRCC1 and XRCC3 genes and susceptibility to breast cancer. Cancer Lett. 2003;190(2):183-90 PubMed PMID: WOS: 000181087900008

47. Smolarz B, Makowska M, Samulak D, Michalska MM, Mojs E, Wilczak M, et al. Association between single nucleotide polymorphisms (SNPS) of XRCC2 and XRCC3 homologous recombination repair genes and triple-negative breast cancer in Polish women. Clin Exp Med. 2015;15(2):151-7 PubMed PMID: WOS:000355568600004.

48. Sobczuk A, Romanowicz-Makowska H, Fiks T, Baszczynski J, Smolarz B. XRCC1 and XRCC3 dna repair gene polymorphisms in breast cancer women from the lodz Region of Poland. Pol J Pathol. 2009;60(2):76-80 PubMed PMID: WOS:000270460500003.

49. Sterpone S, Cornetta T, Padua L, Mastellone V, Giammarino D, Testa A, et al. DNA repair capacity and acute radiotherapy adverse effects in Italian breast cancer patients. Mutat Res Fundam Mol Mech Mutagen. 2010;684(1-2):43-8 PubMed PMID: WOS:000274989500005.

50. Su CH, Chang WS, Hu PS, Hsiao CL, Ji HX, Liao CH, et al. Contribution of DNA Double-strand Break Repair Gene XRCC3 Genotypes to Triple-negative Breast Cancer Risk. Cancer Genomics Proteomics. 2015;12(6):359-67 PubMed PMID: WOS:000364570200007.

51. Thyagarajan B, Anderson KE, Folsom AR, Jacobs DR Jr, Lynch CF, Bargaje A, et al. No association between XRCC1 and XRCC3 gene polymorphisms and breast cancer risk: lowa Women's health study. Cancer Detect Prev. 2006;30(4):313-21.

52. Vral A, Willems P, Claes K, Poppe B, Perletti G, Thierens H. Combined effect of polymorphisms in Rad51 and Xrcc3 on breast cancer risk and chromosomal radiosensitivity. Mol Med Rep. 2011;4(5):901-12 PubMed PMID: 21725594. Epub 2011/07/05. eng.

53. Webb PM, Hopper JL, Newman B, Chen XQ, Kelemen L, Giles GG, et al. Double-strand break repair gene polymorphisms and risk of breast or ovarian cancer. Cancer Epidemiol Biomark Prev. 2005;14(2):319-23 PubMed PMID: WOS:000227113800005.

54. Zhang L, Ruan Z, Hong Q, Gong X, Hu Z, Huang Y, et al. Single nucleotide polymorphisms in DNA repair genes and risk of cervical cancer: a casecontrol study. Oncol Lett. 2012;3(2):351-62.

55. Gonzalez-Hormazabal P, Reyes JM, Blanco R, Bravo T, Carrera I, Peralta O, et al. The BARD1 Cys5575er variant and risk of familial breast cancer in a south-American population. Mol Biol Rep. 2012;39(8):8091-8.
56. Jara L, Dubois K, Gaete D, De Mayo T, Ratkevicius N, Bravo T, et al. Variants in DNA double-strand break repair genes and risk of familial breast cancer in a south American population. Breast Cancer Res Treat. 2010; 122(3):813-22.

57. Consortium BCA. Commonly studied single-nucleotide polymorphisms and breast cancer: results from the breast Cancer association consortium. J Natl Cancer Inst. 2006;98(19):1382-96.

\section{Ready to submit your research? Choose BMC and benefit from:}

- fast, convenient online submission

- thorough peer review by experienced researchers in your field

- rapid publication on acceptance

- support for research data, including large and complex data types

- gold Open Access which fosters wider collaboration and increased citations

- maximum visibility for your research: over $100 \mathrm{M}$ website views per year

At BMC, research is always in progress.

Learn more biomedcentral.com/submissions 